過去に治療歴のある血友病 $A$ 患者に対する

遺伝子組換え型血液凝固第VIII因子製剤（リコネイト）の

市販後の多施設臨床評価（使用成績調査）

\author{
福武勝幸*1, 新井盛大 ${ }^{* 1}$, 稲葉 浩*1, 花房 秀 次 ${ }^{* 2}$, 三間屋純一 ${ }^{* 3}$, \\ 高松 純 樹*4, 吉岡 章*5, 嶋 緑 倫*5, 白幡 聡*6, 藤巻道男 ${ }^{* 7}$, \\ リコネイト (PTPs) 研究会
}

\begin{abstract}
過去に第VIII因子製剂による治療歴のある血友病 A 患者 (PTPs) を対象とした多施設共同の市販後

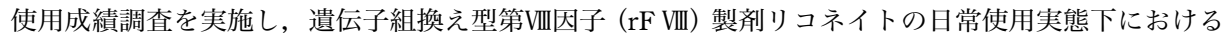
長期 (2 年間) の有効性および安全性を前方視的に検討した. 134 例が症例登録され, 129 例を有効性 および安全性の解析対象とした. 本剤の止血効果は総出血エピソード数 4,171 出血に対し, 著効 1,769 出血, 有効 2,031 出血で, 有効以上の有効率は $91.1 \%$ あった. 非出血時投与の頻度が週 1 回以上 で定期補充療法例と考えられた重症例 21 症例の出血頻度は出血時治療例 32 例に比し, 有意に低い ものであった。副作用は 3 例 $(2.3 \%)$ に認められ, 内訳は頭痛, 萇麻疹および抗 $\mathrm{rF}$ VIII抗体 (IgM) 産 生が各 1 例であった。頭痛および蔚麻疹は軽度で一過性で早期に回復し, 抗 $r F$ VIII抗体 (IgM) 産生 症例では抗体産生に伴う臨床症状はなかった。 なお, 本調査期間中, 新規に第VIII因子インヒビター (Bethesda 法) が発生した症例はなかった，以上より，リコネイトはわが国における PTPs での長期 の使用において安全で有効な製剤であると考えられた.
\end{abstract}

Key words: recombinant factor VIII, post-marketing surveillance, hemophilia A, previously treated patient

\section{緒言}

血友病 Aの治療は, ヒト血漿由来第V四因子 濃縮製剤の登場により, 補充療法としての止血 管理が容易となり，患者の Quality of Life は大き く向上した。一方，これらの製剤はヒト血漿を原 料として使用しているためヒト血液媒介病原微 生物が完全には排除されているとは言えない。
リコネイトはこれら諸問題の解決を目指し開 発された遺伝子組換え型第VII因子製剤であり, 1992 年 12 月に最初の遺伝子組換え型第VIII因子 製剂として米国等で承認され，以来 30 か国以 上で上市され，既に約 70 億単位が使用されて いる.

本剤は欧米において過去に第VIII因子製剤の治 療歴のある血友病 A 患者 (Previously treated

*1 東京医科大学 臨床検査医学講座〔 $=160-0023$ 東京都新宿区西新宿 6-7-1〕

Department of Laboratory Medicine, Tokyo Medical University [6-7-1, Nishi-Shinjyuku, Shinjyuku-ku, Tokyo 160-0023]

Tel: 03-3342-6111 Fax: 03-3340-5448 e-mail: fukutake@tokyo-med.ac.jp

*2 荻窪病院血液科〔干 167-0035 東京都杉並区今川 $3-1-24]$

Department of Hematology, Ogikubo Hospital〔3-1-24, Imagawa, Suginami-ku, Tokyo 167-0035〕

*3 静岡県立こども病院血液腫瘍科〔干 $420-8660$ 静岡県静岡市漆山 860〕

Department of Hematology Oncology, Children's Hospital of Shizuoka Prefecture [860, Urushiyama, Shizuoka City, Shizuoka, 420-8660]

*4 名古屋大学医学部附属病院輸血部〔干 466-8550 愛知県名古屋市昭和区鶴舞町 65〕

Department of Transfusion Medicine, Nagoya University School of Medicine Hospital〔65, Turumai-cho, Showa-ku, Nagoya, Aichi 466-8550]

*5 奈良県立医科大学小児科〔T 634-8522 奈良県橿原市四条町 840〕 Department of Pediatrics, Nara Medical University [840, Shijo-cho, Kashihara City, Nara 634-8522]

*6 産業医科大学小児科〔 $707-8555$ 福岡県北九州市八幡西区医生ヶ丘 1-1〕 Department of Pediatrics, University of Occupational and Environmental Health, Japan〔1-1, Iseigaoka, Yahatanishiku, Kitakyusyu City, Fukuoka, 807-8555]

*7 東洋公衆衛生学院〔干 151-0071 東京都渋谷区本町 6-21-7〕

Toyo Public Health College〔6-21-7, Honmachi, Shibuya-ku, Tokyo 151-0071〕

受付日: 2005 年 4 月 27 日 受理日 : 2005 年 7 月 26 日 
patients: PTPs）を対象に 1987 年以降，市販後 調査を含めた長期臨床試験が実施され，長期使 用において安全かつ有効であったと報告されて いる1).また，欧米において遺伝子組換え型第 VIII因子製剤への切り替えにより第VIII因子インヒ ビターの発生するリスクについて検討され，イ ンヒビター発生の増加はなかったと報告されて いる゙2. 本剤はわが国においては, 血友病 $\mathrm{A}$ 患 者を対象とした臨床試験が 1991 年 1 月から開 始され3) ${ }^{4)}, 1996$ 年 4 月に再審査期間を 6 年間 として承認された。そこでわれわれはPTPsを 対象とした市販後使用成績調査を同年 6 月か ら開始し，本剤の日常使用実態下における長期 間にわたる有効性および安全性を前方視的に検 討したので報告する。

\section{対象および方法}

\section{1. 対 象}

本調査は, PTPs で 1996 年 6 月から 2002 年 3 月までに, リコネイトを使用している患者を 対象とし, リコネイト (PTPs) 研究会の共同研 究として行われた。リコネイト (PTPs) 研究会 の多施設共同研究への参加者は Table 1 のとお りである。なお，使用成績調査のため，除外規 定は設定しなかった。

\section{2. 調査項目}

1) 投与状況

投与ごとに，その投与日，投与量，投与目的， 出血部位および投与前の出血症状等を観察し, 記録した。また，在宅自己注射療法の実施患者 では患者の投与記録により確認した.

\section{2）臨床検査}

一般臨床検査は Table 2 の計画に従って各施 設で実施した。

第VIII因子活性（F VIII：C）は凝固一段法によ り，第VIII因子抗原量 (F VIII : Ag) は ELISA 法) により奈良県立医科大学小児科学教室で測定し た。

第VII因子インヒビターの測定は，SRLでべ
セスダ法で実施し， $1 \mathrm{BU} / \mathrm{mL}$ 以上を陽性とし た。

遺伝子組換え型第VIII因子に対する IgG 抗体 および IgM 抗体（抗 $\mathrm{rF}$ VIII抗体（IgG）および抗 $\mathrm{rF}$ VIII抗体 (IgM))，ならびに製造工程由来の夾 雑たん白である遺伝子組換え型 von Willebrand 因子 $(\mathrm{rVWF})$ ，マウス $\operatorname{IgG}$ ，チャイニーズハム スター卵巣細胞由来たん白およびウシ血清アル ブミンに対する抗体（抗 rVWF 抗体，抗マウス IgG 抗体，抗 CHO 抗体および抗 BSA 抗体) は 東京医科大学臨床検査医学講座にて ELISA 法 で測定した ${ }^{6)}$. 本調査開始時および開始後各時 点の検体を同時測定し得られた吸光度の差（投 与後-投与前）を実測值とし，実測值から反復 切断補正法 (白井法 ${ }^{7)}$ ) を用いてスクリーニン グ検査での陰性基準值を算出した。実測值がこ の陰性基準値を超えた場合には，各種濃度の抗 原を添加し抗体を中和させる blocking test（抗 体中和確認試験）を実施した。投与前の抗体中 和確認試験において陰性と判定された症例で, 投与後 1 回以上陽性と判定された症例は，新規 抗体産生症例と判定した。

3) 有害事象

有害事象について調査し, 内容, 発現時期, WHO Toxicity Grading Criteria $^{8)}$ にしたがって重 篤度, 重症度, 処置, 経過, 転帰および本剤と の因果関係等を詳細に記録した。また，抗体産 生検査成績は，調査期間中の抗体産生に関連す ると考えられる臨床症状等を考慮し，担当医が 有害事象か否かにつき判定した。

\section{3. 有効性・有用性の評価}

1 出血エピソードごとに「著効：止血効果が 十分認められた」,「有効：投与回数と投与日数 を要したが，止血効果が認められた」，「やや有 効：十分ではないが，止血効果が認められた」, 「無効：止血効果が認められなかった」,「悪化： 悪化した」の 5 段階および「判定不能」で，止 血効果を評価した。

有用性は，有効性および安全性を総合的に評 価し,「極めて有用」,「有用」,「やや有用」,「有 


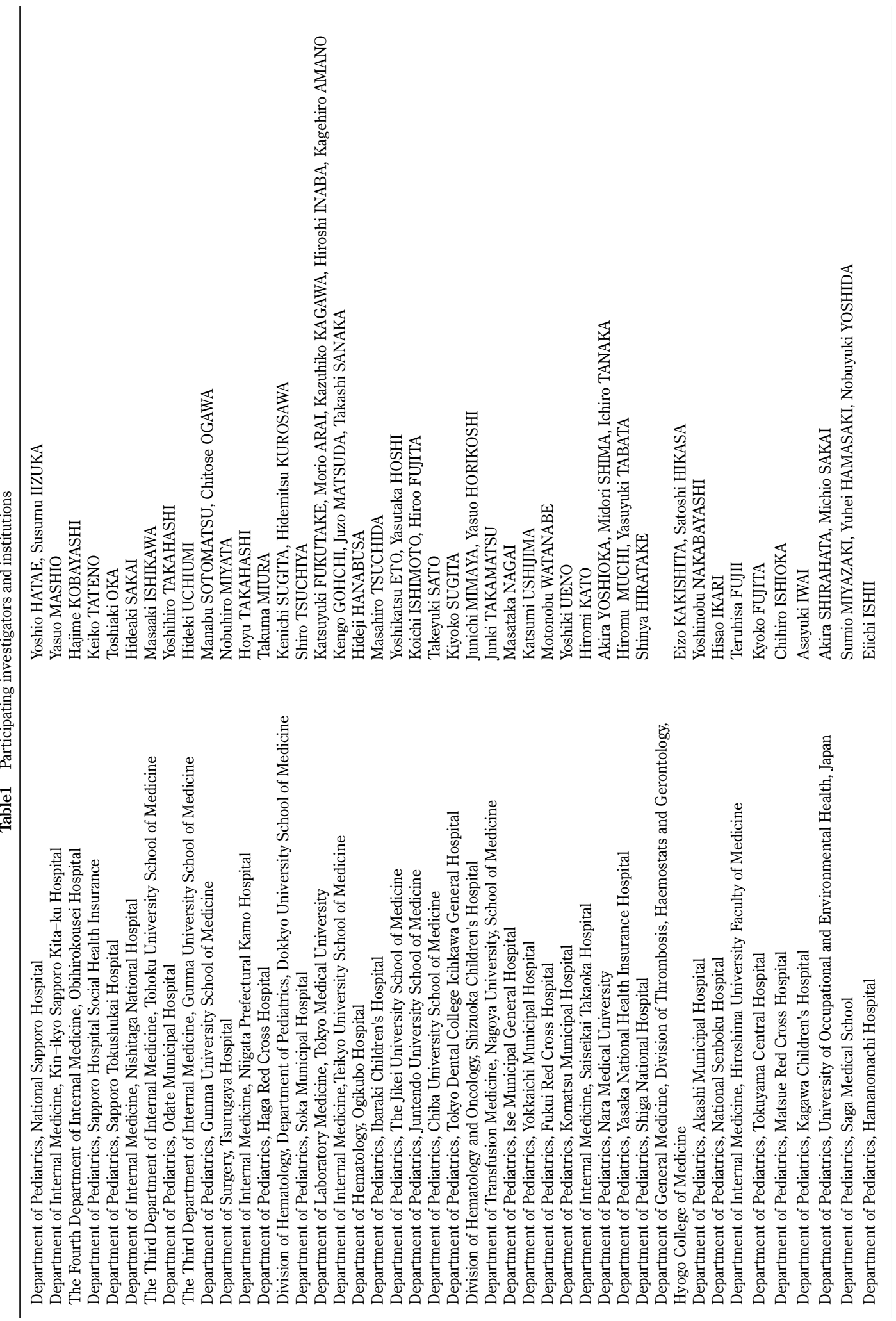


Table 2 Laboratory parameters

\begin{tabular}{|c|c|c|c|c|c|c|c|}
\hline & Test & Baseline $^{1)}$ & 3months & 6months & 12 months & 18 months & 24 months \\
\hline \multirow[t]{3}{*}{ Coagulation } & FVIII : C-inhibitor (Bethesda) $)^{2)}$ & $\bigcirc$ & 0 & O & 0 & O & $\bigcirc$ \\
\hline & FVIII : C & O & & & & & \\
\hline & FVIII : Ag & $\bigcirc$ & & & & & \\
\hline ELISA test & $\begin{array}{l}\text { anti-rFVIII } \mathrm{Ab}(\mathrm{IgG} \text {, IgM), anti-rVWF Ab, } \\
\text { anti-CHO Ab, anti-mouse IgG } \mathrm{Ab} \text {, and } \\
\text { anti-BSA Ab }\end{array}$ & $\bigcirc$ & & $\bigcirc$ & $\bigcirc$ & $\bigcirc$ & $\bigcirc$ \\
\hline Hematology & $\begin{array}{l}\text { RBC, Ht, PLT, WBC, and } \\
\text { WBC differential }\end{array}$ & O & & $\bigcirc$ & $\bigcirc$ & O & $\bigcirc$ \\
\hline Biochemistry & $\begin{array}{l}\text { ALT, ASP, } \gamma-\text { GTP, ALP, LDH, } \\
\text { Total bilirubin, BUN, and Creatinine }\end{array}$ & $\bigcirc$ & & O & $\bigcirc$ & $\bigcirc$ & $\bigcirc$ \\
\hline Virus & $\begin{array}{l}\text { HBsAg, HBsAb, HBcAb, HIV-Ab, and } \\
\text { HCV-Ab }\end{array}$ & O & & & & & $\bigcirc$ \\
\hline
\end{tabular}

1) Pre-infusion after the patient's enrollment

2) to be measured after the infusions and at a month after the infusions when high dose is infused.

FVIII : C ; factor VIII activity, FVIII : Ag ; factor VIII antigen, VWF ; von Willebrand factor,

$\mathrm{CHO}$; Chinese hamster ovary cell-derived protein, BSA ; bovine serum albumin

用性なし」の 4 段階および，「判定不能」で，本 調査終了時に担当医が判定した。

\section{成 績}

\section{1. 対象症例}

134 症例が登録されたが，5例では本剤が投 与されなかったため解析対象から除外した。

有効性および安全性の解析対象となった 129 例には, 1 歳未満の乳児 3 例および 65 歳以上 の高歯者 2 例が含まれ, 年齢は中央值 22 歳（生 後 10 力月〜 74 歳), 体重は中央值 $54 \mathrm{~kg}(8.2$ 〜 $106 \mathrm{~kg}$ ) であった（Table 3). 血友病重症度は, 重症 (F VIII : C < 1\%) 80 例 $(62.0 \%)$, 中等症 ( F VIII : C $1 \sim 5 \%) 37$ 例 (28.7\%), 軽症 (F VIII : C $>5 \%) 12$ 例 $(9.3 \%)$ であった。調査期間は中 央值 2.0 年 $(1$ 日〜 3.0 年) であり, 110 例 (85.3\%) で 2 年以上の成績を収集し得た。有効性解析対 象症例 129 例における総投与回数は 13,736 投 与であり, 内訳は出血時投与が 6,448 投与 (46.9\%)，手術のための投与および定期的補充 療法等が 7,288 投与 (53.1\%) であった。また, 129 例における総出血エピソード数は 4,171 出 血であった (Table 4).

\section{2. 有効性}

1）出血時投与

総計 4,171 回の出血に対し出血エピソードご との止血に要した本剤の投与回数は, 中央值 1 回（1〜 72 回）で，うち，1 回投与が 2,957 出 血, 2 回投与が 778 出血で, 全体の $89.5 \%$ (3,735/4,171 出血) が 2 回までの投与で止血に 至っていた（Table 4).

出血エピソードに対する本剤の総投与回数は 6,448 投与で， 1 回当たりの投与量は，平均 $19.2 \pm 7.4 \mathrm{U} / \mathrm{kg}(0.6 \sim 124.2 \mathrm{U} / \mathrm{kg})$ であった. 全体の $83.1 \%$ (5,356/6,448 投与) は 1 回当たり の投与量が $10 〜 30 \mathrm{U} / \mathrm{kg}$ の範囲内であった (Table 5). 1 出血エピソードごとの止血効果 は, 著効 $42.4 \%$ (1,769/4,171 出血), 有効 $48.7 \%$ $(2,031 / 4,171$ 出血) で, 有効以上の有効率は 91.1\% (3,800/4,171 出血) であった（Table 6). 1 出血エピソード当たりの総投与量は中央值 $20.0 \mathrm{U} / \mathrm{kg}(5.3 \sim 1,265.4 \mathrm{U} / \mathrm{kg})$ であり, 全体 の $85.7 \%(3,576 / 4,171$ 出血) が $50 \mathrm{U} / \mathrm{kg}$ 未満の 総投与量で止血に至っていた。

無効と判定された出血が 2 例 3 出血エピソ ードで認められた（Table 6)。これらは，中等 度〜重度の関節出血でそれぞれ約 $13 \mathrm{U} / \mathrm{kg}$ が, 
Table 3 Patient characteristics

\begin{tabular}{|c|c|c|}
\hline Characteristics & Stratum & No. of patients \\
\hline \multirow[t]{2}{*}{ Gender } & Male & 126 \\
\hline & Female & 3 \\
\hline Age & -6 & 14 \\
\hline \multirow[t]{4}{*}{ (yrs) } & $7-14$ & 27 \\
\hline & $15-30$ & 50 \\
\hline & $30-40$ & 24 \\
\hline & $40-$ & 14 \\
\hline Mean $\pm \mathrm{SD}$ (median, range) & $23.0 \pm 14.7$ & $(22 \mathrm{yrs}, 10 \mathrm{mos}-74 \mathrm{yrs})$ \\
\hline \multirow{7}{*}{$\begin{array}{l}\text { Body weight } \\
(\mathrm{kg})\end{array}$} & -9 & 1 \\
\hline & $10-19$ & 9 \\
\hline & $20-29$ & 9 \\
\hline & $30-59$ & 65 \\
\hline & $60-79$ & 38 \\
\hline & $80-$ & 6 \\
\hline & Unknown & 1 \\
\hline Mean $\pm \mathrm{SD}$ (median, range) & $50.8 \pm 18.7$ & $(54,8.2 \sim 106)$ \\
\hline \multirow{3}{*}{$\begin{array}{l}\text { Severity of hemophilia A } \\
\text { [FVIII : C (\%)] }\end{array}$} & Severe $[<1]$ & 80 \\
\hline & Moderate [1-5] & 37 \\
\hline & Mild $[5<]$ & 12 \\
\hline Mean $\pm \mathrm{SD}$ (median, range) & $2.0 \pm 2.7$ & $(<1,<1 \sim 17.3)$ \\
\hline \multicolumn{3}{|l|}{ Complications } \\
\hline \multirow{2}{*}{ Liver disease } & yes & 81 \\
\hline & no & 48 \\
\hline \multirow[t]{2}{*}{ Hepatitis C } & yes & 79 \\
\hline & no & 50 \\
\hline \multirow[t]{3}{*}{ FVIII : C-inhibitor } & yes & 2 \\
\hline & no & 125 \\
\hline & Unknown & 2 \\
\hline \multirow{4}{*}{$\begin{array}{l}\text { Follow-up period } \\
\text { (yrs) }\end{array}$} & -0.9 & 9 \\
\hline & $1-1.9$ & 5 \\
\hline & $2-$ & 110 \\
\hline & Unknown & 5 \\
\hline Mean \pm SD (median, range) & $1.9 \pm 0.5$ & (2.0yrs, 1day $\sim 3.0 \mathrm{yrs})$ \\
\hline \multirow[t]{7}{*}{ Mean dose per infusion $(\mathrm{U} / \mathrm{kg})$} & -9 & 9 \\
\hline & $10-19$ & 62 \\
\hline & $20-29$ & 32 \\
\hline & $30-39$ & 3 \\
\hline & $40-49$ & 1 \\
\hline & $50-$ & 1 \\
\hline & Unknown & 21 \\
\hline Mean $\pm \mathrm{SD}$ (median, range) & $19.0 \pm 6.8$ & $(18.2,6.4 \sim 51.6)$ \\
\hline \multirow[t]{7}{*}{ Total dose $(\mathrm{U} / \mathrm{kg})$} & -499 & 21 \\
\hline & $500-999$ & 18 \\
\hline & $1,000-1,999$ & 23 \\
\hline & $2,000-2,999$ & 13 \\
\hline & $3,000-4,999$ & 21 \\
\hline & $5,000-$ & 12 \\
\hline & Unknown & 21 \\
\hline Mean $\pm \mathrm{SD}$ (median, range) & $2,148.2 \pm 1,871.7$ & $(1,588.9,9.0 \sim 8,963.2)$ \\
\hline \multirow[t]{6}{*}{ Exposure-days } & -49 & 47 \\
\hline & $50-99$ & 22 \\
\hline & $100-199$ & 27 \\
\hline & $200-299$ & 19 \\
\hline & $300-$ & 6 \\
\hline & Unknown & 8 \\
\hline Mean $\pm \mathrm{SD}$ (median, range) & $110.1 \pm 96.6$ & $(83,1 \sim 368)$ \\
\hline \multirow[t]{5}{*}{ Cumulative no. of bleeding episodes } & -9 & 26 \\
\hline & $10-49$ & 67 \\
\hline & $50-99$ & 17 \\
\hline & $100-$ & 8 \\
\hline & Unknown & 11 \\
\hline Mean $\pm \mathrm{SD}$ (median, range) & $35.3 \pm 33.8$ & $(26,1 \sim 150)$ \\
\hline
\end{tabular}


Table 4 Relationship of bleeding site to number of infusions per bleeding episode

\begin{tabular}{|c|c|c|c|c|c|c|c|}
\hline \multirow[t]{2}{*}{$\overline{\text { Bleeding site }}$} & \multicolumn{6}{|c|}{ Number of infusions } & \multirow[t]{2}{*}{ Total (\%) } \\
\hline & 1 & 2 & 3 & 4 & $5 \leqq$ & Unknown & \\
\hline Joint & 2336 & 594 & 176 & 72 & 46 & 2 & $3226(77.3)$ \\
\hline Muscle & 188 & 88 & 24 & 21 & 12 & 0 & $333(8.0)$ \\
\hline Subcutaneous & 208 & 48 & 13 & 6 & 9 & 0 & $284(6.8)$ \\
\hline Oral & 79 & 10 & 2 & 1 & 1 & 0 & $93(2.2)$ \\
\hline Hematuria & 9 & 4 & 3 & 3 & 1 & 0 & $20(0.5)$ \\
\hline Two or more sites & 32 & 15 & 5 & 18 & 6 & 0 & $76(1.8)$ \\
\hline Others ${ }^{*}$ & 105 & 19 & 4 & 3 & 8 & 0 & $139(3.3)$ \\
\hline Total & 2957 & 778 & 227 & 124 & 83 & 2 & $4171(100)$ \\
\hline$(\%)$ & $(70.9)$ & $(18.7)$ & $(5.4)$ & $(3.0)$ & $(2.0)$ & $(0.05)$ & \\
\hline
\end{tabular}

*: Epistaxis(79), traumatic(17), odontorrhagia(7), lip(5), otic(4), gastrointestinal(3), etc.

Table 5 Relationship of bleeding site to dose per infusion

\begin{tabular}{|c|c|c|c|c|c|c|c|c|}
\hline \multirow[t]{2}{*}{ Bleeding site } & \multicolumn{5}{|c|}{ Dose(U/kg) } & \multicolumn{3}{|r|}{ Total (\%) } \\
\hline & -9 & $10-19$ & $20-29$ & $30-39$ & $40-49$ & $50 \leqq$ & Unknown & \\
\hline Joint & 336 & 2781 & 1204 & 197 & 95 & 12 & 108 & $4733(73.4)$ \\
\hline Muscle & 34 & 349 & 191 & 32 & 9 & 2 & 15 & $632(9.8)$ \\
\hline Subcutaneous & 44 & 234 & 110 & 14 & 7 & 6 & 13 & $428(6.6)$ \\
\hline Oral & 12 & 46 & 14 & 34 & 4 & 0 & 4 & $114(0.7)$ \\
\hline Hematuria & 0 & 30 & 0 & 15 & 0 & 1 & 0 & $46(1.8)$ \\
\hline Two or more sites & 12 & 191 & 35 & 4 & 1 & 7 & 9 & $259(4.0)$ \\
\hline Others & 7 & 144 & 27 & 14 & 3 & 4 & 37 & $236(3.7)$ \\
\hline Total & 445 & 3775 & 1581 & 310 & 119 & 32 & 186 & $6448(100)$ \\
\hline$(\%)$ & $(6.9)$ & $(58.5)$ & $(24.5)$ & $(4.8)$ & (1.8) & $(0.5)$ & $(2.9)$ & \\
\hline
\end{tabular}

Table 6 Relationship of hemostatic efficacy to bleeding site

\begin{tabular}{|c|c|c|c|c|c|c|c|c|c|}
\hline \multirow[t]{2}{*}{ Bleeding site } & \multicolumn{7}{|c|}{ Hemostatic efficacy per bleeding episode } & \multirow[t]{2}{*}{ Total } & \multirow{2}{*}{$\begin{array}{c}\text { Efficacy rate (\%) } \\
{[\text { Excellent }+ \text { Good }]}\end{array}$} \\
\hline & Excellent & Good & Fair & None & Worse & Unevaluable & Unknown & & \\
\hline Joint & 1375 & 1574 & 253 & 3 & 0 & 20 & 1 & 3226 & 91.4 \\
\hline Muscle & 116 & 181 & 35 & 0 & 0 & 1 & 0 & 333 & 89.2 \\
\hline Subcutaneous & 141 & 120 & 23 & 0 & 0 & 0 & 0 & 284 & 91.9 \\
\hline Oral & 45 & 41 & 7 & 0 & 0 & 0 & 0 & 93 & 92.5 \\
\hline Hematuria & 7 & 10 & 2 & 0 & 0 & 0 & 1 & 20 & 85.0 \\
\hline Two or more sites & 17 & 41 & 18 & 0 & 0 & 0 & 0 & 76 & 76.3 \\
\hline Others & 68 & 64 & 4 & 0 & 0 & 3 & 0 & 139 & 95.0 \\
\hline Total & 1769 & 2031 & 342 & 3 & 0 & 24 & 2 & 4171 & 91.1 \\
\hline$(\%)$ & $(42.4)$ & $(48.7)$ & $(8.2)$ & $(0.1)$ & & $(0.6)$ & $(0.05)$ & $(100)$ & \\
\hline
\end{tabular}

1 〜 回投与されたが出血状況の改善が認めら れず無効と判定された。しかし, 悪化すること なくその後止血に至っている．悪化と判定され た出血は認められなかった。

2）定期補充療法等および手術のための投与

105 例に対して総計 7,288 回の投与が行われ た. 目的別にみると, 定期補充療法等 7,128 投 与 $(97.8 \%)$, 手術時等 74 投与 $(1.0 \%)$, 抜歯時 43 投与 $(0.6 \%)$, ならびに，その他 43 投与
(0.6\%) であった。定期補充療法等は, 運動等 の前および再出血予防のための投与を含んでお り，手術時等は生検および眼科処置時の投与を 含んでいる。

重症例で週 1 回以上の定期補充療法が行わ れた症例と出血時投与のみの症例における出血 頻度を Table 7 に示した。主治医により合併症 として血友病性関節症等の記載のない例では, 定期補充療法をしている 21 例と出血時のみの 


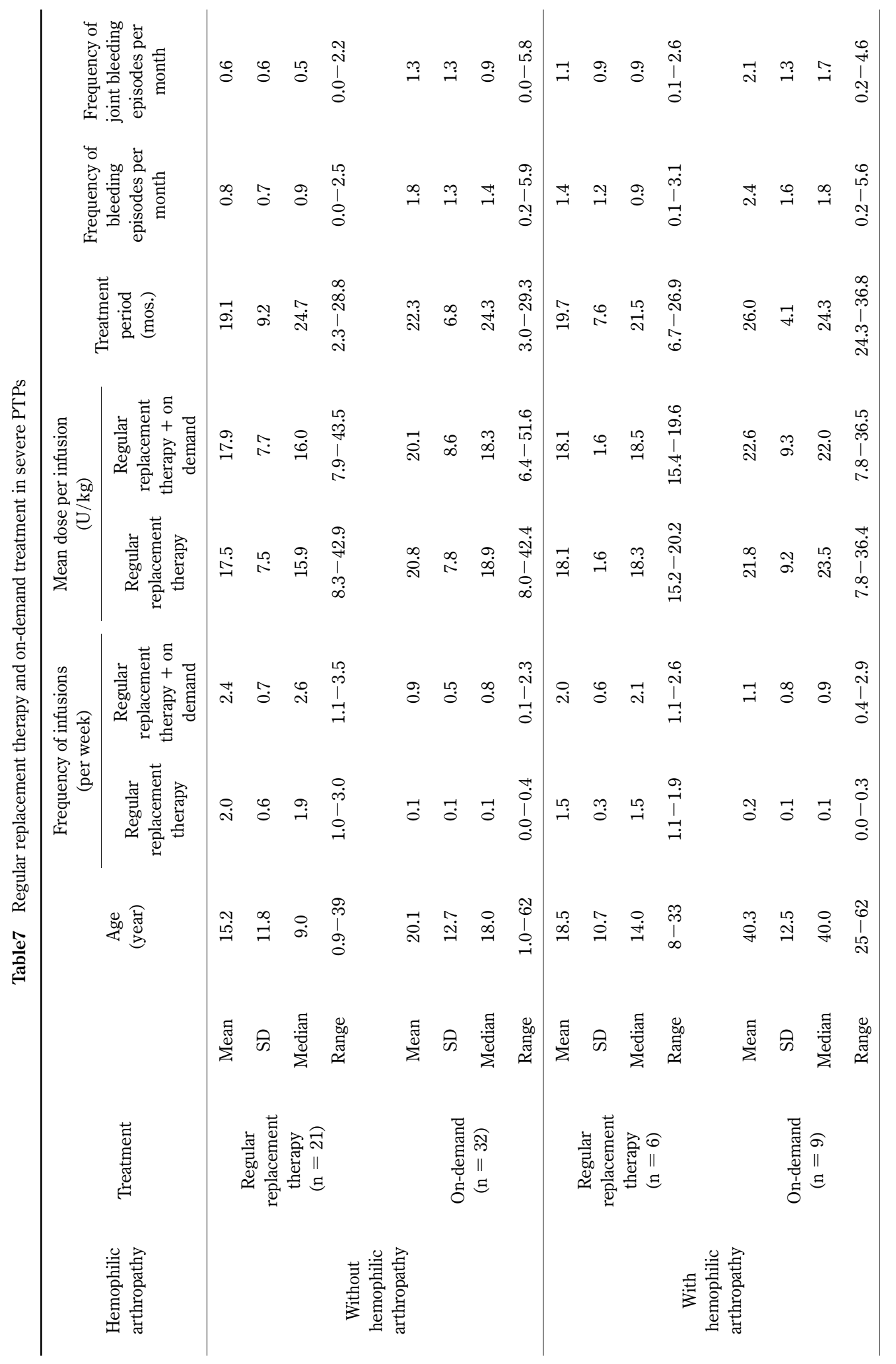




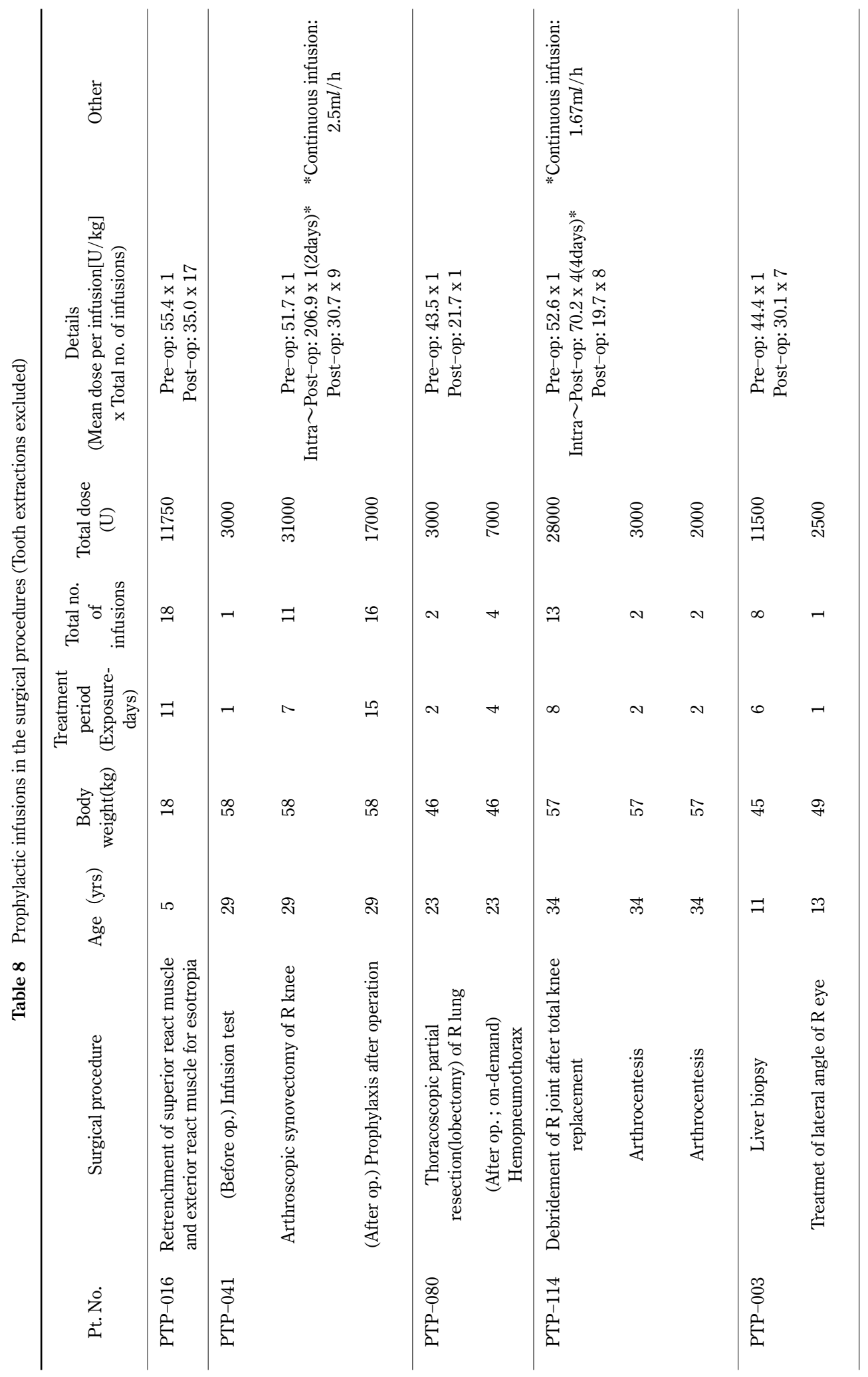


Table 9 Hemostatic efficacy by patient characteristics

\begin{tabular}{|c|c|c|c|c|}
\hline Characteristic & Stratum & $\begin{array}{c}\text { No. of } \\
\text { patients }\end{array}$ & $\begin{array}{l}\text { No. of bleeding } \\
\text { episodes }\end{array}$ & Efficacy rate $(\%)$ \\
\hline \multirow[t]{2}{*}{ Gender } & Male & 126 & 4,130 & 91.4 \\
\hline & Female & 3 & 41 & 58.5 \\
\hline Age & -6 & 14 & 320 & 95.3 \\
\hline \multirow[t]{4}{*}{ (yrs) } & $7-14$ & 27 & 854 & 90.4 \\
\hline & $15-30$ & 50 & 1,561 & 88.0 \\
\hline & $30-40$ & 24 & 891 & 94.4 \\
\hline & $40-$ & 14 & 545 & 93.4 \\
\hline Body weight & -9 & 1 & 11 & 100 \\
\hline \multirow[t]{6}{*}{$(\mathrm{kg})$} & $10-19$ & 9 & 235 & 97.9 \\
\hline & $20-29$ & 9 & 208 & 92.3 \\
\hline & $30-59$ & 65 & 2,417 & 91.6 \\
\hline & $60-79$ & 38 & 1,099 & 89.8 \\
\hline & $80-$ & 6 & 201 & 82.6 \\
\hline & Unknown & 1 & 0 & - \\
\hline \multirow[t]{3}{*}{ Severity of hemophilia A } & severe & 80 & 2,720 & 90.8 \\
\hline & moderate & 37 & 1,365 & 91.3 \\
\hline & mild & 12 & 86 & 97.7 \\
\hline \multirow[t]{2}{*}{ Complicated liver disease } & yes & 81 & 2,920 & 91.6 \\
\hline & no & 48 & 1,251 & 89.8 \\
\hline \multirow[t]{3}{*}{ FVIII : C-inhibitor } & yes & 2 & 63 & 95.2 \\
\hline & no & 125 & 4,102 & 91.0 \\
\hline & Unknown & 2 & 6 & 100 \\
\hline \multirow{4}{*}{$\begin{array}{l}\text { Follow-up period } \\
\text { (yrs) }\end{array}$} & -0.9 & 9 & 48 & 97.9 \\
\hline & $1-1.9$ & 5 & 16 & 87.5 \\
\hline & $2-$ & 110 & 4,107 & 91.0 \\
\hline & Unknown & 5 & 0 & - \\
\hline \multirow[t]{7}{*}{ Mean dose per infusion(U/kg) } & -9 & 9 & 354 & 94.1 \\
\hline & $10-19$ & 62 & 2,432 & 92.8 \\
\hline & $20-29$ & 32 & 986 & 91.8 \\
\hline & $30-39$ & 3 & 173 & 72.3 \\
\hline & $40-49$ & 1 & 12 & 100 \\
\hline & $50-$ & 1 & 24 & 87.5 \\
\hline & Unknown & 21 & 190 & 77.4 \\
\hline \multirow[t]{7}{*}{ Total dose $(\mathrm{U} / \mathrm{kg})$} & -499 & 21 & 183 & 89.1 \\
\hline & $500-999$ & 18 & 499 & 92.6 \\
\hline & $1,000-1,999$ & 23 & 1,013 & 93.7 \\
\hline & $2,000-2,999$ & 13 & 703 & 86.6 \\
\hline & $3,000-4,999$ & 21 & 953 & 94.4 \\
\hline & $5,000-$ & 12 & 630 & 90.5 \\
\hline & Unknown & 21 & 190 & 77.4 \\
\hline \multirow[t]{6}{*}{ Exposure-days } & -49 & 47 & 646 & 91.0 \\
\hline & $50-99$ & 22 & 967 & 87.3 \\
\hline & $100-199$ & 27 & 1,580 & 93.5 \\
\hline & $200-299$ & 19 & 676 & 94.1 \\
\hline & $300-$ & 6 & 278 & 88.8 \\
\hline & Unknown & 8 & 24 & 29.2 \\
\hline \multirow[t]{5}{*}{ Cummulative no. of bleeding episodes } & -9 & 26 & 109 & 90.8 \\
\hline & $10-49$ & 67 & 1,822 & 89.4 \\
\hline & $50-99$ & 17 & 1234 & 90.8 \\
\hline & $100-$ & 8 & 1006 & 94.6 \\
\hline & Unknown & 11 & 0 & - \\
\hline
\end{tabular}


投与 32 例を比較すると 1 力月当たりの出血頻 度は，定期補充療法群の平均 $0.8 \pm 0.7$ 回/月 に対し, 出血時投与群では平均 $1.8 \pm 1.3$ 回/月 $(\mathrm{p}<0.01)$, 関節への出血頻度は, 定期補充療 法群の平均 $0.6 \pm 0.6$ 回/月に対し, 出血時投与 群では平均 $1.3 \pm 1.3$ 回/月であった $(\mathrm{p}<0.02)$. また，主治医により合併症として血友病性関節 症等の記載のある症例で同様に, 定期補充療法 を行っている 6 例と定期補充療法を行ってい ない 9 例を比較すると 1 力月当たりの出血頻 度は, 定期補充療法群の $1.4 \pm 1.2$ 回/月に対 し, 出血時投与群では平均 $2.4 \pm 1.6$ 回/月 (NS), 関節への出血頻度は, 定期補充療法群 の平均 $1.1 \pm 0.9$ 回/月に対し, 出血時投与群 では平均 $2.1 \pm 1.3$ 回/月であった (NS).

外科的処置時の止血管理状況を Table 8 に示 した.内斜視のため外直筋および上直筋短絡術 (症例 16), 右膝関節鏡下滑膜切除術 (症例 41），胸腔鏡下右肺部分切除術（症例 80）なら びに右膝人工関節置換術後感染病巣掻爬術（症 例 114）が各 1 例各 1 回の計 4 回の手術が施行 された. また, 関節穿刺が 1 例 2 回施行され (症 例 114), 肝生検が 1 回および右眼角部処置が 1 回施行された（症例 3).

抜歯は 13 例で 31 回行われ，抜歯前に平均 $21.2 \pm 8.3 \mathrm{U} / \mathrm{kg}(8.2 \sim 43.5 \mathrm{U} / \mathrm{kg})$ が投与され た.このうち 9 例での 12 回の抜歯では抜歯後に 追加投与され, 平均 $19.3 \pm 9.2 \mathrm{U} / \mathrm{kg}(8.2 \sim 40.0$ $\mathrm{U} / \mathrm{kg}$ ) が $1 \sim 3$ 回投与された. 1 回の抜歯に要 した総投与量は平均 $58.1 \pm 30.7 \mathrm{U} / \mathrm{kg} （ 16.3$ $108.7 \mathrm{U} / \mathrm{kg}$ ) であった.

その他は歯科および耳鼻科処置のため 4 例 8 投与, 内視鏡検査のため 2 例 3 投与および頭部 打撲のため 2 例 3 投与であった. 歯科および耳 鼻科処置のための投与量は平均 $18.1 \pm 2.0$ $\mathrm{U} / \mathrm{kg}(15.2 \sim 22.3 \mathrm{U} / \mathrm{kg})$, 内視鏡検査の投与 量は平均 $17.2 \pm 2.3 \mathrm{U} / \mathrm{kg}(14.6 \sim 18.5 \mathrm{U} / \mathrm{kg})$ であった。また，頭部打撲のための 1 回投与量 は平均 $27.9 \pm 21.9 \mathrm{U} / \mathrm{kg}(12.6 \sim 52.9 \mathrm{U} / \mathrm{kg})$ で，投与回数は全て 1 回であった.
3）止血効果に影響を及ぼす要因

患者背景因子別有効率を Table 9 に示した。 有効性に影響を与えると考えられる患者背景因 子は特に認められなかった。

なお，女性で有効率 $58.5 \%$ と低值となった が，女性例 3 例のうち，1例は投与データが入 手できず，有効性の判定から除外したため，関 節症を有する 1 例と他の 1 例の 2 例のみで集 計したものである.

また, 調査開始時に F VIIIインヒビターを保 有していた 2 例は本剤で良好に止血管理され た. 1 例（症例 21）の F VIIIインヒビターは調査 期間中 $1 \sim 2 \mathrm{BU} / \mathrm{ml}$ で, 本剤は 1 回当たり平 均 $28.6 \mathrm{U} / \mathrm{kg}$ を $1 \sim 2$ 回投与され，有効率は 100\% (39/39 出血) であった。他の 1 例（症例 73）の F VIIIインヒビターは調査期間中 $2 \sim 13$ $\mathrm{BU} / \mathrm{ml}$ であったが, 本剤を 1 回当たり平均 $51.6 \mathrm{U} / \mathrm{kg}, 1 \sim 4$ 回投与され，有効率は $87.5 \%$ (21/24 出血) であった。

\section{F VIIIインヒビター}

本調査期間中，新規に F VIIIインヒビターが 発生した症例はなかった。

\section{4. 夾雑たん白および rF VIIIに対する抗体}

夾雑たん白および $\mathrm{rF}$ VIII対する抗体の新規 産生率を Table 10 に, 各抗体の新規産生症例で の調査期間中の検査結果を Table 11 に示した.

抗 BSA 抗体，抗 rVWF 抗体および抗 $\mathrm{CHO}$ 抗体の新規産生症例率は，それぞれ $3.5 \%$ (4/114 例), $0.9 \%$ (1/117 例) および 0.9\% (1/115 例）であった。いずれの症例でも抗体産生に伴 うと考えられる臨床症状は全く認められなかっ た。抗マウス $\operatorname{IgG}$ 抗体の新規産生症例は認め られなかった。

抗 $\mathrm{rF}$ VIII抗体（IgG）および抗 $\mathrm{rF}$ VIII抗体（IgM） の新規産生症例率は，それぞれ $0.9 \%(1 / 117$ 例）および $1.7 \%$ (2/116 例) であった。いずれ の症例でも調査期間中，抗体産生に伴う臨床症 状および F VIIIインヒビター発生は認められな かった。抗 $\mathrm{rF}$ VIII抗体（IgG）の陽転化は一過性 であり, 抗 $\mathrm{rF}$ VIII抗体（IgM）の新規産生症例 2 
Table 10 Serologic responses

\begin{tabular}{lccc}
\hline Antibody & $\begin{array}{c}\text { No. of evaluable } \\
\text { patients }\end{array}$ & \multicolumn{2}{c}{ Newly development of antibody } \\
\cline { 3 - 4 } & 114 & No. of patients & Rate $(\%)$ \\
\hline anti-BSA Ab & 117 & 1 & 3.5 \\
anti-rVWF Ab & 115 & 1 & 0.9 \\
anti-CHO Ab & 116 & 0 & 0.9 \\
anti-mouse IgG Ab & 117 & 1 & 0.0 \\
anti-rFVIII Ab(IgG) & 116 & 2 & 0.9 \\
anti-rFVIII Ab(IgM) & & & 1.7 \\
\hline
\end{tabular}

Tabel 11 Test results in the patients with positive serologic responses

\begin{tabular}{lccccccc}
\hline Antibody & Pt. no. & Baseline & $6 \mathrm{mos}$ & $12 \mathrm{mos}$ & $18 \mathrm{mos}$ & $24 \mathrm{mos}$ & Other \\
\hline anti-BSA Ab & 48 & - & + & N.T. & N.T. & - & \\
& 49 & - & - & - & - & + & Negative after the study close \\
& 58 & - & - & - & + & - & \\
\hline anti-rVWF Ab & 113 & - & - & - & + & - & \\
\hline anti-CHO Ab & 48 & - & + & N.T. & N.T. & - & \\
\hline anti-rFVIII Ab(IgG) & 93 & - & + & - & N.T. & - & Negative after the study close \\
\hline anti-rFVIII Ab(IgM) & 40 & - & - & - & - & + & Negative after the study close \\
& 60 & - & - & - & - & + & \\
\hline
\end{tabular}

例では調査終了時 (24 力月後) に抗体が陽転化 し，1例（症例 40）は担当医により有害事象と 判定され，副作用症例として報告したが，調査 終了後の追跡調査で陰性化し, 臨床症状は認め られなかった。

\section{5. 副作用}

安全性解析対象 129 例中 3 例 $(2.3 \%)$ に 3 件 の副作用が認められた。内訳は頭痛 (症例 43), 莍麻疹 (症例 113) および前述の抗 $\mathrm{rF}$ VIII抗体 (IgM) 産生（症例 40）が各 1 例 1 件であった。 頭痛および蔚麻疹は軽度かつ一過性で無処置に て早期に回復した。また，抗 $\mathrm{rF}$ VIII抗体（IgM） は力価も低值で, 調査終了後の追跡調査にて陰 性が確認された。

なお，他の臨床検査所見に関しては本剤に起因 すると考えられる検査值異常変動は認められな かった.

\section{6. 有用性}

129 例中 57 例 $(44.2 \%)$ が極めて有用， 62 例 (48.1\%) が有用， 1 例 $(0.8 \%)$ がやや有用，お よび 4 例 (3.1\%) が判定不能と判定され，5例 (3.9\%) が不明であり, 有用性なしと判定され
た症例は認められなかった。極めて有用と有用 を合わせた有用以上は $92.2 \%$ あっった。

\section{考察}

今回，われわれはバクスター社からの依頼に 基づき，わが国において生後 10 カ月から 74 歳 までの PTPs 症例 129 例を対象とした市販後使 用成績調查を多施設共同研究 (43 施設) として 前方視的に実施し，本剤の市販後の日常使用実 態下における補充療法剂としての長期の有効性 および安全性を検討した。

有効以上の有効率 $91.1 \%(3,800 / 4,171$ 出血) で，患者背景因子別有効率の検討において有効 性に影響を与えると考えられる注目すべき患者 背景因子は認められなかった。この成績は本剤 の第 III 相臨床試験での有効率 95.8\%（574/599 出血. $)^{4)}$ と同程度であることより，本剤は市販 後の長期使用においても有効性に変化はな く，十分に有効であると考えられた。また，本 剤の海外における PTPs を対象とした長期臨床 試験での有効率は $91.2 \%$ であり ${ }^{1)}$, 他の遺伝子 
組換え第VII因子製剤および従来のヒト血漿由来 第VIII因子製剤の臨床試験での有効率 $98.8 \%{ }^{9)}$ お よび $92.9 \%{ }^{10)}$ と比較しても本剤は, 同程度の 有効性があると考えられた。

近年，北欧において， Nilsson ${ }^{11)} や$ Astermark $^{12)}$ らは，2 歳以下の小児期早期に定期補充療法を 開始した症例では，1 年間当たりの関節出血回 数は少なく, 整形外科的関節スコアや X 線評 価による関節スコアも Oであったことを報告 し, 1 次定期補充療法が血友病患者の QOLを 改善することを指摘している. その一方で, 定 期的補充療法によるコストの増加, 血管確保の 難しさや心理的負担などの問題点が指摘され, MRI を含む関節初期変化の評価方法や適切な プロトコールなど13) 14) について検討が進められ ている. 国内においても瀧ら ${ }^{15)}$ は日本小児血液 学会を中心にプロトコールの検討をすすめ, 2004 年 11 月の第 46 回日本小児血液学会血友 病委員会セッションにおいて試験開始が報告さ れている。

本調査において, 重症例 80 例のうち, 投与 回数が週 1 回以上で定期補充療法が実施され ていたと考えられた症例が 27 例認められた。 定期補充療法症例と考えられる症例における出 血頻度は, 出血時投与が主な症例に比し少ない 傾向が認められ, 関節障害のない 21 例では有 意に低く, 定期的補充療法の有効性が示唆され た。

安全性の検討では解析対象症例 129 例にお いて新規に F VIIIインヒビターが発生した症例 はなかった。1999 年国際血栓止血学会 (ISTH) 科学的標準化委員会 (SSC) の FVIII および FIX に関する小委員会は治療歴のない症例 (PUPs) を対象とする臨床試験はウイルスに対する安全 性評価やインヒビター発生の natural history の 評価に重要であるが, 凝固因子製剤の免疫原性, すなわち，第VII因子製剤の変更により新たな抗 原性が生じ F VIIIインヒビターが発生する可能 性を評価するためには, 凝固因子製剤の実投与 日数（EDs）が 150 日を超えたPTPs 症例で検
証すべきとしている 販後使用成績調査として計画されたものである ため登録時までのそれぞれの患者の実投与日数 は確認されていない.しかしながら，本調査期 間中, 新規に F VIIIインヒビターが発生した症 例はなく，本剤はPTPs における F VIIIインヒビ ターの発生のリスクが, 極めて低いと考えられ た.

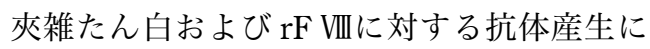
ついて検討した結果では, 新規抗体出現症例率 は抗 BSA 抗体 $3.5 \%$, 抗 rVWF 抗体 $0.9 \%$, 抗 $\mathrm{CHO}$ 抗体 $0.9 \%$, 抗 $\mathrm{rF}$ VIII抗体 (IgG) $0.9 \%$ およ び抗 $\mathrm{rF}$ VIII抗体（IgM）1.7\%であり，抗マウス $\mathrm{IgG}$ 抗体産生症例は認められなかった. 海外で, 血友病 PTPs の 68 例および健常成人 57 名およ び小児 100 名での夾雑たん白に対する抗体産 生の検討 ${ }^{17)}$ が行われている. 抗 BSA 抗体, 抗 $\mathrm{CHO}$ 抗体および抗マウス $\operatorname{IgG}$ 抗体の産生症例 率はPTPs でそれぞれ 7.9\%，4.4\%および $6.8 \%$ であり，また，健常人での抗体陽性率は，成人 ではそれぞれ $14.0 \%, 1.8 \%$ および 19.3\%，小 児ではそれぞれ $71.0 \% ， 10.0 \%$ おび $53.0 \%$ で あった。国内で実施されたリコネイトの治療歴 のない症例 (PUPs) において抗 BSA 抗体出現 率は $15 \%(3 / 20)^{18)}$ であり, また, 本調査にお ける検査法と同じ方法で行った健常小児 36 名 での抗 BSA 抗体を検討した結果は 15 名 (41.7\%) で陽性で，28 から 58 歳の健常成人 30 名での抗 BSA 抗体を検討した結果は 5 名 （16.7\%）で陽性であったことを確認してい る ${ }^{6)}$. 新規に抗体が産生された症例においても, これらによる臨床症状は認められなかった. Kazukawa $~^{19)}$ は健常小児 87 名の抗 BSA 抗体 を測定し, 特に 4 歳未満で抗体価が高い傾向を 報告しており, 食物等の環境因子の持続的な抗 原暴露による自然経過である可能性を指摘して いる. なお，欧米での PTPs における産生率が わが国での成績より全体的に高值であったの は, 両者の検査法において判定方法が異なるた めと考えられる，すなわち，わが国では調査開 
始前後のペア検体の吸光度差が陰性基準值を超 えたものにつき抗体中和確認試験を実施した上 で陽性と判定しているのに対し, 欧米では各検 体と同時測定した正常プール人血清の吸光度と 比較して陽性と判定したためと考えられた。

これらから，本剤の投与による夾雑たん白お よび $\mathrm{rF} V \mathrm{VII}$ に対する抗体産生率は低く, 臨床的 にも特に問題となり得るものではないと考えら れた。

6 年間の市販後使用成績調査より, 重篤な副 作用は報告されず，リコネイトは血友病 $\mathrm{A}$ 患 者の治療製剤として長期の使用において安全で 有効な製剤であると考えられた。

\section{文献}

1) White GC II , Courter S, Bray GL, Lee M, Gomperts ED, the Recombinant Previously Treated Patient Study Group : A multicenter study of recombinant factor VIII $\left(\right.$ Recombinate $^{\mathrm{TM}}$ ) in previously treated patients with hemophilia A. Thromb Haemost 77 : 660-667, 1997.

2) Scharrer I, Ehrlich HJ : Lack of evidence for increased inhibitor incidence in patients switched from plasma-derived to recombinant factor VIII . Haemophilia $7: 346-348,2001$.

3）藤巻道男, 田中朝志, 福武勝幸, 浜英永, 松田重三, 嶋 緑倫, 福井弘, 西田恭治, 垣下榮三, 白幡聡：血友病 $\mathrm{A}$ 患者に対する遺伝子組換え第VII因子製剂 BL-160 の臨床 評価. 血栓止血誌 4 : 179-188, 1993.

4）藤巻道男，武田武夫，畑江芳郎，豊田隆謙，石川正明， 柴田昭, 高橋芳右, 松田重三, 浜英永, 福武勝幸, 田中 朝志, 稲垣稔, 花房秀次, 本多康次郎, 三間屋純一, 斎 藤英彦, 高松純樹, 緒方完治, 島田司巳, 太田茂, 吉岡章, 嶋緑倫, 辻野儀一, 木下清二, 垣下榮三, 西田恭治, 白 幡聡：血友病 A 患者に対する遺伝子組換え血液凝固第VII 因子製剂 $(\mathrm{BL}-160)$ の多施設臨床評価. 血栓止血誌 4: 430-440, 1993.

5) Kamisue S, Shima M, Nishimura T, Tanaka I, Nakai H, Morichika S, Takata N, Kuramoto A, Yoshioka A : Abnormal factor VIII Hiroshima:defect in crucial proteolytic cleavage by thrombin at $\mathrm{Arg}^{1689}$ detected by a novel ELISA. Br J Hematol 86 : 106-111, 1994.

6）稲葉浩，新井盛夫，福武勝幸，金東賢，花房秀次，三間 屋純一, 高松純樹, 嶋緑倫, 吉岡章, 白幡聡, 藤巻道男: 遺伝子組換え型第VW因子製剂（リコネイト）の市販後調 査一抗体検査を中心に一。血栓止血誌 $14: 480,2003$.

7）白井敏明：正常值計算法：反復切断補正法における切断 係数の選択. 臨床病理 24:319-322, 1981.

8) Edwards I.R.,: Harmonisation in Pharmacovigilance. Drug Safety $10: 93-102,1994$

9) 福井弘, 森和夫, 石川正明, 柴田昭, 高橋芳右, 藤巻道男, 福武勝幸, 腰原公人, 木下忠俊, 中山明子, 浜英永, 稲
垣稔, 花房秀次, 三間屋純一, 斎藤英彦, 神谷忠, 高松 純樹, 白川茂, 出口克巳, 吉岡章, 嶋緑倫, 安永幸二郎, 大久保進, 吉岡慶一郎, 木下清二, 垣下榮三, 西田恭治, 白幡聡：遺伝子組換えヒト第V西因子製剂 BAYw6240 の多 施設共同による臨床的検討 (長期投与試験)。日輸血会誌 37 : 593-604, 1991.

10）藤巻道男，後藤三雄，宮崎保，櫻田恵右，森和夫，石川 正明, 木下忠俊, 福武勝幸, 稲垣稔, 花房秀次, 長尾大, 高橋芳右, 松田保, 塩原信太郎, 斎藤英彦, 吉岡慶一郎, 木下清二, 安永幸二郎, 大久保進, 垣下榮三, 西田恭治, 上田一博, 小林正夫, 白幡聡：モノクローナル抗体精製 第VIII因子濃縮製剂（RCG-11）の臨床試験成績. 基礎と臨 床 $26: 299-319,1992$.

11) Nilsson IM, Berntorp E, Lofqvist T, Pettersson H : Twentyfive years' experience of prophylactic treatment in severe haemophilia A and B. J Intern Med 232 : 25-32, 1992.

12) Astermark J, Petrine P., Tengborn L, Schulman S, Ljung R, Berntorp E,: Primary prophylaxis in severe haemophilia should be started at an early age but can be individualized. Br. J Haematol 105 : 1109-1113, 1999.

13) Shapiro A.D.:A global view on prophylaxis: possibilities and consequences. Haemophilia 9. Suppl.1 10-18, 2003.

14) Manco-Johnson M.J., Pettersson H., Petrini P., Babyn P.S., Bergstrom B-M., Bradley C-S., Doria A.S., Feldman B.M., Funk S., Hillirad P., Kilcoyne R., Lundin B., Nuss R., Rivard G., Schoenmakers M.A.G.C., van den Berg M., Wiedel J.: Physical therapy and imaging outcome measures in a haemophilia population treated with factor prophylaxis: current status and future directions. Haemophilia 10 : Suppl.4 88-93, 2004

15）瀧正志：血友病予防投与の現状. 血栓止血誌 13 ： 109-113, 2002.

16) White G.C., DiMechele D., Mertens K., Negrier C., Peake I.R., Prowse C., Schwaab R., Yoshioka A., Ingerslev J.: Utilization of previously treated patients (PTPs), noninfected patietns (NIPs), and previously untreated patients (PUPs) in the evaluation of new factor VIII and factor IX concentrates. Recommendation of the Scientific Subcommittee on Factor VIII and Factor IX of the Scientific and Standardization Committee of the International Society on Thrombosis and Haemostasis. Thromb Haemost. 81 : 462, 1999.

17) Ingerslev J., Christiansen K., Ravn H.B., Bray G.L., Gomperts E.D., The Recombinant Study Group : Antibodies to heterologous proteins in hemophilia A patients receiving recombinant factor VIII (RecombinateTM). Thromb Haemost 87 : 626-634, 2002.

18）吉岡章，福武勝幸，新井盛夫，稲葉浩，花房秀次，三間 屋純一, 高松純樹, 嶋緑倫, 白幡聡, 藤巻道男, リコネ イト (PUPs) 研究会 : 過去に治療歴のない血友病 A 患者 に対する遺伝子組換え型血液凝固第VW因子製剤 (リコネ イト）の市販後の多施設臨床評価（特別調査）．血栓止血 誌, $15: 522-534,2004$.

19) Kazukawa M., Sugihara S., Sakamaki T., Konda S., Murata A., Wataki K., Kobayashi Y., Minamitani K., Miyamoto S., Sasaki N., Niimi H.: Antibodies to bovine serum albumin in Japanese IDDM children; No association with GAD antibodies and HLA risk genotypes. Clin Pediatr Endocrinol. 6 : 23-31, 1997. 


\title{
A multi-center post-marketing surveillance study of recombinant factor VIII (Recombinate) in previously treated patients with hemophilia A
}

\author{
Katsuyuki FUKUTAKE, Morio ARAI, Hiroshi INABA, \\ Hideji HANABUSA, Jun-ichi MIMAYA, Junki TAKAMATSU, \\ Akira YOSHIOKA, Midori SHIMA, Akira SHIRAHATA, \\ Michio FUJIMAKI, and the Recombinate (PTPs) Study Group
}

Key words: recombinant factor VIII, post-marketing surveillance, hemophilia A, previously treated patient

A multi-center post-marketing surveillance study was conducted in previously treated patients with hemophilia A in order to evaluate the safety and efficacy of a recombinant factor VIII (Recombinate) in the long term (2 years) management and prevention of bleeding episodes. One hundred thirty-four patients were enrolled into this study and 129 patients were found to be evaluable. In total, 4,171 bleeding episodes were assessed during the study period and, hemostatic efficacy was judged to be excellent in 1,769 and good in 2,031 episodes with an overall efficacy rate of 91.1\% . Twenty-one patients received at least one regular replacement therapy per week with the recombinant factor VIII during this study. These patients manifested much less spontaneous bleeding episodes than the patients who had received ondemand treatments. Three adverse reactions were reported in three patients (2.3\%): i.e., urticaria in one, and headache in two patients, each being only mild and transient. One patient developed an IgM antibody to recombinant the factor VIII, which was not associated with any clinical symptoms. No patients developed the inhibitor to factor VIII in Bethesda assay. These results indicate that the recombinant factor VIII, Recombinate, is safe and efficacious for the long-term management and prevention of bleeding episodes in patients with hemophilia $\mathrm{A}$, who had previously received replacement treatments with factor VIII concentrates. 